\title{
Study of market conditions for the marketing of solid shampoo
}

\section{Estudio de condiciones de mercado para la comercialización de Shampoo sólido}

\author{
GONZÁLEZ-VÁZQUEZ, Isidro†*, ÁNGEL-GARCÍA, Martha Patricia and ARTEAGA- \\ ITURRARÁN, Raul
}

Universidad Tecnológica de Jalisco. Col. Luis J. Jiménez 577, $1^{\circ}$ de Mayo, 44979, Guadalajara, Jalisco, Mex.

ID $1^{\text {er }}$ Author: Isidro, González-Vázquez / ORC ID: 0000-0003-4854-9038, CVU CONACYT ID: 914192

ID $1^{\text {er }}$ Coauthor: Martha Patricia, Ángel-García / ORC ID: 0000-0001-6277-603X, CVU CONACYT ID: 280802

ID $2^{\text {nd }}$ Coauthor: Raul, Arteaga-Iturrarán / ORC ID: 0000-0001-9217-9658, CVU CONACYT ID: 915209

DOI: $10.35429 / J G E .2019 .5 .3 .11 .10$

Received July 17, 2019; Accepted December 15, 2019

Abstract

The research work aimed to analyze the feasibility of the business model "Solid Shampoo IUHCAYO" in Guadalajara. Shampoo IUHCAYO consists of the launch of an organic product for hair care, which aims to offer a healthier product that is also organic and product for hair care, which aims to offer a healthier product that is also organic and
environmentally friendly. It aims to replace liquid shampoo products with solid stick shampoo, thus reducing the use of plastic packaging in addition to reducing harmful hair chemicals with this organic product. In addition to having high standards of quality and exceptional service. Through a probabilistic sampling, individuals were located who contacted the guadalajara metropolitan area who subsequently shared the instrument until a sufficient sample and with the specific characteristics of our Segment. The type of questions used was that of closed questions, multiple selection with only answer. Finally, this market research concludes that at least for the sample studied, the product is feasible from a marketing and marketing perspective and it is recommended to apply more research tools in order to deepen and study the acceptance of bar shampoo. General Objective. Identify the availability of the market to acquire the Shampoo bar in the Metropolitan Zone of Guadalajara. Methodology. A quantitative study was conducted taking as a data collection tool a survey applied in the Metropolitan Zone of Guadalajara to a representative sample of 1,067 surveys of men and women over the age of 18 with a confidence level of $95 \%$ and a margin of error of $3 \%$. The survey was conducted by simple random subsampling by clusters and random home routes. Contribution. This study has three important purposes:

1. Incorporation and participation of students from the career of Engineering in Development and Business Innovation in project initiated pro students of TSU Environmental Technology to identify areas of commercial opportunity of the product. 2. Awareness and active participation of the university community, consumers and the general public in relation to the sustainability and care of the environment.

3 . The results of the study will serve as the basis for the design and realization of a business plan.

Market Research, Solid Shampoo, Commercial Viability

\begin{abstract}
Resumen
El trabajo de investigación tuvo como objeto analizar la viabilidad del modelo de negocios "Shampoo sólido IUHCAYO" en Guadalajara. Shampoo IUHCAYO consiste en el lanzamiento de un producto orgánico para el cuidado del cabello, el cual tiene como finalidad ofrecer un producto más saludable que además de orgánico es amigable con el ambiente. Se tiene como objetivo del modelo de negocios reemplazar los productos de shampoo líquido por shampoo solido en barra, de esta manera se reducirá el uso de envases shampoo líquido por shampoo solido en barra, de esta manera se reducirá el uso de envases de plástico además de reducir los químicos dañinos para el cabello con este producto
orgánico. Además de tener altos estándares de calidad y servicio excepcional. Mediante orgánico. Además de tener altos estándares de calidad y servicio excepcional. Mediante un muestreo probabilístico se localizaron individuos los cuales se contactaron en la zona metropolitana de Guadalajara que posteriormente compartieron el instrumento hasta
conseguir una muestra suficiente y con las características específicas de nuestro segmento. conseguir una muestra suficiente y con las características específicas de nuestro segmento. El tipo de preguntas usado fue el de preguntas cerradas, de selección múltiple con única
respuesta. Finalmente, esta investigación de mercados permite concluir que al menos para respuesta. Finalmente, esta investigación de mercados permite concluir que al menos para la muestra estudiada, el producto es viable desde la perspectiva de mercadeo y
comercialización y se recomienda aplicar más instrumentos de investigación para poder comercialización y se recomienda aplicar más instrumentos de investigación para poder profundizar y estudiar la aceptación del shampoo en barra. Objetivo General. Identificar la disponibilidad de mercado para adquirir el Shampoo en barra en la Zona Metropolitana de Guadalajara. Metodología. Se realizó un estudio cuantitativo teniendo como instrumento de recolección de datos una encuesta aplicada en la Zona Metropolitana de Guadalajara a una muestra representativa de 1,067 encuestas a hombres y mujere mayores de 18 años con un nivel de confianza del $95 \%$ y un margen de error del $3 \%$. La encuesta fue realizada por submuestreo aleatorio simple por conglomerados y rutas aleatorias domiciliarias. Contribución. El presente estudio tiene tres propósitos importantes:

1. Incorporación y participación de los estudiantes de la carrera de Ingeniería en Desarrollo e Innovación Empresarial en proyecto iniciado pro estudiantes de TSU de Tecnología Ambiental para identificar áreas de oportunidad comercial del producto. 2. Concientización y participación activa de la comunidad universitaria, consumidores y público en general en relación a la sustentabilidad y cuidado del medio ambiente.

3. Los resultados del estudio servirán de base para el diseño y realización de plan de negocios.
\end{abstract}

Investigación de mercados, Shampoo sólido, Viabilidad comercial

Citation: GONZÁLEZ-VÁZQUEZ, Isidro, ÁNGEL-GARCÍA, Martha Patricia and ARTEAGA-ITURRARÁN, Raul. Study of market conditions for the marketing of solid shampoo. RINOE Journal-General Economics. 2019. 3-5: 11-13.

\footnotetext{
* Correspondence to Author (email: igonzalez@utj.edu.mx)

$\dagger$ Researcher contributing first author.
} 


\section{Introduction}

For years we have been using the same ingredients in our shampoo. Most of these products aimed at hair care contain harmful ingredients causing weakness in the hair, dryness of the scalp or even hormonal changes, affecting the health, silkiness and appearance of it. The business model idea of a solid IUHCAYO Shampoo began with the observation of the needs that people, mainly women, have when taking care of their hair. With the advent of organic cosmetics, new ingredients have also arrived, they are no longer all the same. Now formulators have hundreds of more sustainable and safe options.

Currently the interest in the quality of hair care products is due to the innumerable benefits that its measurement reports, among which is to enhance the number of loyal users, increase the number of customers, present opportunities for the development of the organization, reduce costs, strengthen the permanence of its members, but, above all, improve the image of the organization. In addition, that, in a scenario characterized by competitiveness, the commitment to quality leads to a competitive advantage that is difficult to overcome; therefore, the evaluation of the quality of the product is a fundamental factor to face the new times.

\section{Development of Sections and Sections of the Article with subsequent numbering}

\section{Problem Statement}

The present investigation wants to specifically solve the need to know the acceptance of the business model implementation, replacing conventional shampoos with a new organic bar model.

As this is a new brand in the market, it is necessary to have all possible quantitative and qualitative tools that allow the distribution and consumption in them to be associated. In modern society there is a revolution of environmentally friendly products as well as organic. That is why it is more frequent day to day to find these types of products on the market, both for hair, skin or health care.
Thanks to this, there is an increasing sympathy of consumers for trying new products. It is important then to find the market that is interested in this type of organic products, that are healthy or healthy and finally that is novel in its presentation.

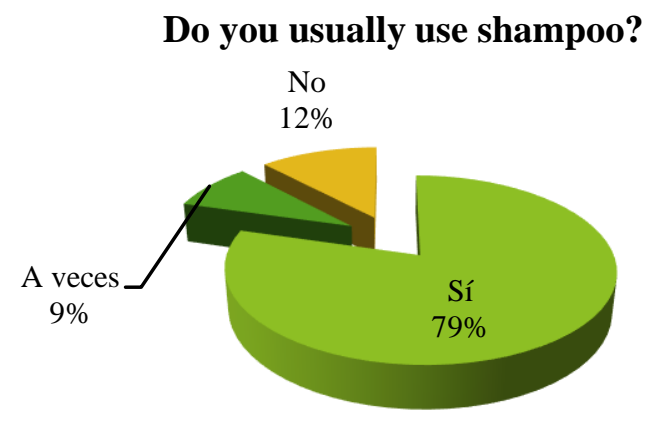

Graphic 1 "Frequency of use of shampoo"

Source: own elaboration based on survey results July 2019

\section{Where do you usually buy your hair care products?}

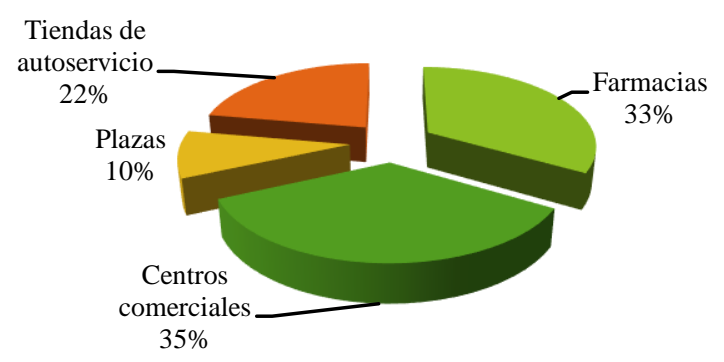

Graphic 2 "Places of purchase"

Source: own elaboration based on survey results July 2019

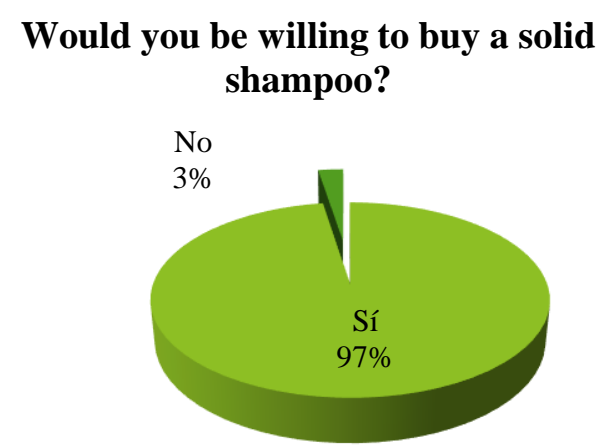

Graphic 3 "Provision of purchase of solid shampoo" Source: own elaboration based on survey results July 2019 
How much would you be willing to pay for a solid shampoo with natural ingredients?

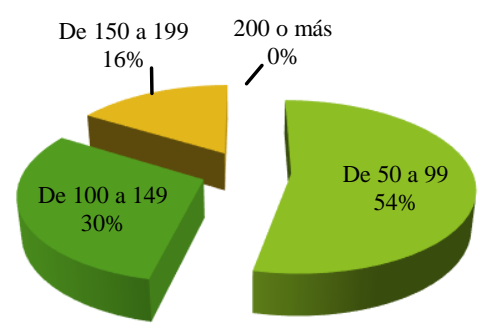

Graphic 3 "Price perceived by the consumer" Source: own elaboration based on survey results July 2019

\section{Results}

As the results show in all this research, the Shampoo has a favorable acceptance in the interviewed population, since apparently the fact that it is organic is something that gives them confidence and their acceptance is favorable. This market study also lets us know what is the approach with which it should be commercialized, since the place where it is reflected that the interviewed population would buy the shampoo in bars are in pharmacies and specialized stores, since it is an organic shampoo, the Customer reflects that he expects it to be something specialized and a product that is sold especially in places. That would be the most appropriate approach for the customer to be totally convinced to buy that product. Also, it should be noted that the client does not expect to pay more than 200 pesos for the same product, and that is something that will have to be taken into consideration, since the costs of this organic shampoo do not seem to coincide with what the client expects to pay for it.

\section{Acknowledgments}

For the present investigation, 8th grade students participated in the design and field work. Semester of the Degree in Engineering in Development and Business Innovation of the Technological University of Jalisco:

- Ana Silva Ramirez.

- Karen Agripino Flores.

- Liliana Núñez Díaz.

- Adalid Espinoza Zuñiga.

- Stephanie Avalos Ibarra.

ISSN-On line: $2524-2008$

RINOE $^{\circledR}$ All rights reserved.

\section{- Andrés Gorozpe.}

Likewise, the support and facilities granted by Mtra. Karina Guevara Chacón, Director of the Administrative Economic Division of the Technological University of Jalisco.

\section{Conclusions}

As this research has shown, the realization of the study has been very useful for the project, since in this way important data were obtained to determine the needs that potential consumers have about the product. There is strong competition in the market that would cause a greater effort of the project to offer added value, unlike the rest of competing products. As an observation and recommendation by the research team, we determine that it is necessary to modify the image and name of the product, since through research we realize that the name of the shampoo is already in the competitive market, likewise create penetration strategies and add an added value, so that the price of the product exceeds the amount that the customer would be willing to pay for it.

\section{References}

INEGI. Censo de población y vivienda 2010. consulta, Julio del 2019

Namakforoosh, M. N. (2005). Metodologia de la investigación. México: Editorial Limusa, S.A. DE C.V.

Naresh, M. (2012). Investigación de Mercados Un Enfoque Práctico. Prentice Hall. ISBN 9789702611851

Philip, K. (2002). Dirección de Marketing Conceptos Esenciales. 14 ED. Prentice Hall. ISBN 9786073212458 